\title{
SEJAUH MANA GURU MENGGUNAKAN METAFORA DALAM KEPEDULIANNYA UNTUK MENINGKATKAN KEMAMPUAN MATEMATIKA SISWA
}

\author{
Oleh: \\ Idrus Alhaddad \\ Program Studi Pendidikan Matematika FKIP Universitas Khairun Ternate \\ Idrus ekal@yahoo.co.id
}

\begin{abstract}
Belajar matematika masih merupakan hal yang sulit bagi siswa, karena disamping memiliki objek kajian yang abstrak, juga berdasarkan pada pola pikir yang deduktif. Untuk membantu siswa dapat memahami bahkan menjadi senang dalam belajar matematika, hal ini tidak terlepas dari peranan guru. Bagi guru, memahami matematika juga merupakan hal yang sulit, dan lebih sulit lagi adalah mengajarkan kepada siswa untuk dapat dipahami. Karena hal itu membutuhkan strategi, metode, dan pendekatan. Dalam pembelajaran matematika banyak hal yang harus diperhatikan. Di antaranya adalah faktor-faktor yang mempengaruhi kegiatan belajar siswa yaitu: pengalaman, kemampuan, kematangan, dan motivasi siswa. Oleh karena itu, baik teori maupun metode dalam pembelajaran harus disesuaikan dengan kondisi siswa. Agar pembelajaran matematis menjadi bermakna dan dimaknai siswa, maka diperlukan caracara khusus untuk menjadikan siswa termotivasi belajar matematika. Salah satunya adalah penggunaan Metafora. Metafora dapat dipandang sebagai suatu strategi untuk membantu siswa dalam memahami matematika. Makalah ini akan menyajikan tentang apa sebenarnya metafofa, bagaimana menggunakannya dalam pembelajaran dan contoh penggunaannya serta kelebihan dalam menggunakan metafora
\end{abstract}

Kata kunci : Kepedulian, Metafora, Pembelajaran Matematika

Mathematics, for most of students, is still considered to be a difficult subject to learn because it does not only possess abstract objects of investigation but it is also based on deductive mindset. Enabling students to understand or even be enjoy learning mathematics, then, will demands good teachers' roles. For teachers, understanding mathematics is also difficult as well. In fact, the most difficult thing for them is how to teach mathematics that can be easily and quickly understood by students. That is why; mathematics teachers need to use exact strategies, methods and approaches. In mathematics learning, there are many things to consider. One of which is factors influencing students' learning activities, namely: their experience, ability, maturation, and motivation. That is why; we, as teachers, need to create learning methods and theories which are adaptive to students' condition. In order to create meaningful mathematics learning which in turn students get the real meaning of it at last, then, we need to use special ways for enabling students to get motivated in learning mathematics. One of these ways is using metaphor. This can be considered as a strategy to help students understand mathematics. This paper will present about what metaphor really looks like, how to use it in learning activities; also, the examples of its use and the benefits we can get from using it in learning will be explained.

Key Words: Concern, Metaphor, Mathematics Learning. 


\section{Pengantar}

Matematika merupakan sesuatu yang tidak dapat dipisahkan dalam kehidupan kita. Sejak dari bangun tidur sampai tidur kembali, kita selalu berhubungan dengan matematika. Segala aktifitas kita selalu dapat dihubungkan dengan matematika. Namun ironisnya, masih banyak siswa yang mengangap matematika merupakan sesuatu yang tidak disenangi, menakutkan bahkan dibenci.

Tentu saja, tidak semua kesalahan ini harus ditimpakan kepada guru. Banyak faktor yang dapat dikiatkan dengan kondisi siswa tersebut. Misalnya penyusunan kurikulum, kurangnya pengetahuan orang tua, kurangnya fasilitas belajar yang memadai, kurangnya guru yang profesional, kurangnya kepedulian guru, cara mengajar guru yang monoton dan sebagainya.

Russeffendi (2006: 468) mengemukakan ada sepuluh faktor yang mempengaruhi keberhasilan siswa dalam belajar antara lain sebagai berikut: (1) kecerdasan, (2) kesiapan belajar, (3) bakat, (4) kemauan belajar, (5) minat, (6) cara penyajian materi pembelajaran, (7) pribadi dan sikap pengajar, (8) suasana pengajaran, (9) kompetensi pengajar, dan (10) kondisi masyarakat luas.

Dari kesepuluh poin tersebut menunjukkan bahwa cara penyajian materi menjadi salah satu upaya untuk meningkatkan kualitas pembelajaran. Apakah penyampaiannya membuat siswa tertarik dan termotivasi untuk mempelajari matematika dengan baik dan timbul perasaan bahwa saya butuh matematika. Ataukah penyampaian yang dilakukan justru membuat siswa bosan dan merasa tidak ada gunanya belajar matematika.

Banyak alterantif yang bisa dilakukan agar penyajian materi pelajaran dapat lebih menarik. Salah satu alternatif tersebut adalah dengan menggunakan metafora. Dengan metafora siswa dapat lebih memahami dan memaknai matematika tidak sekedar menghafal rumus. Metafora yang diberikan dapat berupa cerita-cerita sukses, perumpamaan-perumpamaan atau simulasi. Setelah pembelajaran siswa diharapkan memiliki wawasan yang lebih tentang kehidupan nyata yang akan dilaluinya kelak, sehingga motivasi mereka untuk lebih sungguh- sungguh dalam memahami pelajaran matematika dapat ditingkatkan. Penyajian materi dengan metafora dalam pembelajaran memiliki peranan penting untuk meningkatkan minat dan motivasi belajar siswa, karena penyajian metafora membawa siswa ke dalam suasana yang penuh kegembiraan dan keharuan, sehingga menciptakan kegembiraan serta pemaknaan dalam proses belajar selanjutnya. Penelitian menyampaikan kepada kita bahwa tanpa keterlibatan emosi, kegiatan saraf otak itu kurang dari yang dibutuhkan untuk merekatkan pelajaran dalam ingatan". Sedangkan seseorang akan belajar dengan segenap kemampuan apabila dia menyukai apa yang dia pelajari dan dia akan merasa senang terlibat di dalamnya.

Untuk dapat memahami dan menggunakan metafora dlam pembelajaran, guru dituntut untuk selalu meningkatkan kemampuannya, baik materi maupun cara penyajiannya. Hal ini dpat dilakukan dengan sungguh sungguh, apabila guru tersebut 
memeliki kepedulian yang tinggi terhadap anak didiknya.

\section{Kepedulian Guru}

Kepedulian guru terhadap kemampuan siswa merupakan suatu sikap yang terlahir dari rasa sayang, tanggung jawab dan mau berbuat untuk kebaikan siswanya. Kalau seorang guru sudah peduli akan siswanya, maka dia akan berbuat yang terbaik untuk keberhasilan siswanya. Seperti halnya orang tua yang peduli kepada anaknya, maka segala cara akan dilakukan untuk membuat anaknya bahagia sesuai dengan keinginan anaknya.

Rasa kepedulian itu dapat diwujudkan melalui Noticing (mencermati). Seorang guru yang peduli akan anak didiknya, akan selalu mencermati untuk melihat perkembangan dan hambatan dari anak didiknya. Mencermati merupakan suatu kegiatan umum dalam pembelajaran, akan tetapi menurut Goleman, mencermati yang efektif itu kompleks dan menantang. Dalam beberapa tahun, psikolog telah mengkaji bagaimana kita menghadirkan stimulus dalam lingkungan kita, dan para peneliti telah mempelajari tidak hanya pada fokus dan kapasitas yang terbatas.

Kepedulian guru dalam mencermati siswanya di kelas, diantaranya yaitu cara berpikir matematika siswa sehingga lebih terarah, mengetahui maknanya yang pada akhirnya lebih lama untuk dingat dan siswa lebih memahami untuk apa matematika yang telah dipelajarinya.

Ada tiga kemampuan menurut Victoria R. Jacobs, etc (2010: 172) yang dapat diamati pada siswa yaitu:

1. Memperhatikan strategi siswa

2. Menginterpretasikan Pemahaman Matematika Siswa

3. Memutuskan Bagaimana Merespon Pemahaman Dasar Anak

\section{Metafora}

Metafora merupakan pemakaian kata atau kelompok kata bukan dengan arti yang sebenarnya, melainkan sebagai lukisan, kiasan, atau perumpamaan yang berdasarkan persamaan atau perbandingan. Misalnya "tulang punggung" dalam kalimat pemuda adalah "tulang punggung" negara.

Metafora juga merupakan kegiatan memaparkan cerita tentang hakikat kesuksesan, perumpamaan-perumpamaan mengenai suatu bentuk kehidupan yang akan mereka hadapi kelak, simulasi, ataupun kisah-kisah berbagai orang sukses dalam hidupnya, serta legenda-legenda lainnya. Melalui penggunaan Metafora dalam kegiatan pembelajaran, diharapkan siswa memiliki wawasan yang lebih tentang kehidupan nyata yang akan mereka hadapi sehingga motivasi mereka dalam belajar dapat ditingkatkan.

Selanjutnya, Waluyo (2008) menyatakan bahwa Metafora adalah salah satu 
alternatif solusi pembelajaran matematika untuk meningkatkan minat dan motivasi siswa dalam belajar matematika, sehingga diharapkan pemaknaan siswa terhadap proses pembelajaran matematika terjadi dengan lebih baik. Ini didukung oleh pendapat beberapa ahli yang telah lama berkecimpung dalam penelitian tentang kinerja otak, di antaranya,

1. De Porter, (2000:14) menyatakan bahwa penyajian materi dengan Metafora dalam pembelajaran memiliki peranan penting untuk meningkatkan minat dan motivasi belajar siswa, karena penyajian Metafora akan membawa siswa ke dalam suasana yang penuh kegembiraan dan keharuan. Kondisi ini menciptakan pemaknaan dalam proses belajar selanjutnya.

2. Menurut Lakoff and Núñez (2000), metaphors generate a conceptual relationship between a source domain and a target domain by mapping and preserving inferences from the source to the target domain. Because metaphors link different senses, they are essential for people in building meanings for mathematical entities "... a large number of the most basic, as well as the most sophisticated, mathematical ideas are metaphorical in nature"

3. Howard and Gardner (dalam De Porter, 2000:23) menyatakan bahwa seseorang akan belajar dengan segenap kemampuan apabila dia menyukai apa yang dia pelajari dan dia akan merasa senang terlibat di dalamnya.

4. Clark (2007) menemukan bahwa, "that stories and literature are particularly rich stimulus to promote mathematical discussion, and when students were asked to provide written reflection about a range of mathematical concepts that were made more accessible and memorable as a result of reading stories."

Bentuk-bentuk metafora yang dapat digunakan atau disampaikan dalam setiap pembelajaran sangat banyak sekali seperti yang diungkapkan oleh (Suherman dalam Sapa'at, 2007), di antaranya yaitu: (1) bercerita dengan menggunakan perumpamaan untuk menumbuhkan kesadaran betapa pentingnya pembelajaran tersebut, (2) bercerita dengan perumpamaan, bahwa yang bertanggungjawab terhadap pendidikan pada hakikatnya adalah diri sendiri, (3) memberikan penjelasan bagaimana kiat meraih sukses dalam pembelajaran dan kehidupan, (4) menyajikan paparan bahwa orang belajar harus siap keluar dari zona nyaman, (5) mendiskusikan mengapa hingga saat ini kualitas pendidikan Indonesia masih terpuruk, (6) mengisahkan tentang beberapa tokoh terkenal seperti Albert Einstein, J.K. Rowling, Syeikh Ahmad Yassin, Jacky Chan, David Bechkam, Michael Jordan, Thomas Alfa Edison, Jalaludin Rumi, Umar Khayyam, dan Sebagainya, atau (7) memberikan beberapa nasihat dan tips-tips untuk meraih keberhasilan. Pada pembelajaran geometri, tahap-tahap belajar anak dalam belajar geometri pada teorema Van Hiele yang meliputi tahap pengenalan (visualisasi), analisis, pengurutan, deduksi dan akurasi

Ada tiga kategori dari metafora, yaitu:

1. Intangible metaphor (metafora yang tidak diraba), yang termasuk kategori ini misalnya suatu konsep, suatu idea, kondisi manusia atau kualitas-kualitas khusus (individual, naturalistis, komunitas, tradisi dan budaya). 
2. Tangible Metaphor (metafora yang dapat diraba), dapat dirasakan dari suatu karakter visual atau material.

3. Combined Metaphors (penggabungan antara keduanya), di mana secara konsep dan visual saling mengisi sebagai unsur-unsur awal dan visualisasi.

Dari ungkapan-ungkapan yang dikemukakan oleh para ahli di atas dapat disimpulkan bahwa metafora adalah suatu bentuk penggunaan kata atau kalimat yang bertujuan untuk mewakili suatu konsep tertentu. Metafora digunakan untuk memahami sesuatu yang abstrak menjadi konkrit atau juga sebaliknya.

\section{Pembelajaran Matematika}

Belajar matematika menurut sebagian besar siswa sangat sulit, matematika bahkan dianggap momok bagi siswa. Hal ini tidak terlepas dari peranan guru. Bagi guru, memahami matematika juga merupakan hal yang cukup rumit, dan lebih rumit lagi adalah mengajarkan kepada siswa untuk dapat dipahami. Karena hal itu membutuhkan strategi, metode, pendekatan. Dalam pembelajaran matematika banyak hal yang harus diperhatikan. Di antaranya adalah faktor-faktor yang mempengaruhi kegiatan belajar siswa yaitu: pengalaman, kemampan, kematangan, dan motivasi siswa. Oleh karena itu, baik teori maupun metode dalam pembelajaran harus disesuaikan dengan kondisi siswa yang bersangkutan.

Dalam melaksanakan pembelajaran matematika di kelas ada beberapa kiat yang bisa dilakukan menurut Holil (2007), di antaranya adalah:

1. Mulailah dari apa yang diketahui anak, bukan dari apa yang diketahui guru.

2. Sajikan matematika dalam suasana menyenangkan.

3. Beri siswa kesempatan sebanyak-banyaknya untuk berbicara, bekerja, dan menulis mengenai matematika.

4. Gunakan bahasa yang biasa (familiar bagi anak) sebagai strategi awal.

5. Padukan matematika dengan pelajaran lain.

6. Manfaatkan rekayasa teknologi (kalkulator dan komputer).

7. Gunakan media pembelajaran yang mudah diperoleh dan menarik.

8. Biasakan menyelesaikan suatu permasalahan dengan pendekatan problem solving.

9. Biasakan siswa untuk aktif bekerjasama dalam kelompok (cooperative learning)

Ada lima kompetensi matematis yang perlu dikembangkan dalam pembelajaran matematis menurut (Klipatrick dan Findell dalam Herman, 2006) yaitu:

1. Conceptual Understanding (pemahaman konsep), yaitu pemahaman konsep, operasi dan relasi dalam matematika.

2. Procedural Fluency(kelancaran prosedural), yakni keterampilan menyelesaikan masalah prosedural secara fleksibel, akurat dan efisien.

3. Strategic Competence (kompetensi strategis), yaitu kemampuan untuk memformulasikan, mempresentasikan, serta menyelesaikan masalah matematik.

4. Adaptive Reasoning (Penalaran adaptif), yakni kapasitas untuk berpikir secara 
logis, reflektif, eksplanatif dan jastifikatif.

5. Productive Disposition (sikap produktif), yakni tumbuhnya sikap positif serta kebiasaan melihat matematika sebagai sesuatu yang logis, berguna dan berfaedah.

Agar pembelajaran matematis menjadi bermakna dan dimaknai siswa, maka diperlukan cara-cara khusus untuk menjadikan siswa termotivasi belajar matematika. Berkaitan dengan hal ini, (Sapa'at, 2007) menyatakan bahwa, "Beberapa cara dapat digunakan untuk membuat siswa menjadi termotivasi belajar matematika dan memiliki sikap menghargai keilmuan matematika itu sendiri, salah satunya adalah penggunaan Metafora di awal, di tengah dan di akhir kegiatan pembelajaran."

\section{Contoh Penggunaan Metafora dalam Pembelajaran Matematika}

Pembentukkan suasana yang kondusif untuk mengajarkan matematika kepada siswa, adalah dengan merencanakan aktivitas pembelajaran yang baik, memberikan penghargaan pada setiap respons yang disampaikan oleh siswa, dan bersikap fleksibel terhadap jawaban atau pendapat siswa. Di samping itu, pengajar juga perlu membebaskan siswa dari ancaman dan ketertekanan yang dirasakannya ketika mencoba mengajukan pendapatnya. Penyajian materi pembelajaran dengan menggunakan metafora dapat dilakukan di awal sebagai apersepsi, pertengahan, ataupun di akhir pembelajaran. Di awal pembelajaran metafora yang diberikan adalah sebagai berikut:

a. Memacu motivasi siswa untuk lebih memaknai hakikat belajar, mengembangkan kesadaran siswa untuk dapat berbuat yang terbaik dan meraih kesuksesan dalam pembelajaran matematika secara khusus, maupun dalam kehidupan yang mereka jalani secara umum.

b. Pengajar memberikan informasi tentang pengertian dan pentingnya pembelajaran matematika yang akan dilaksanakan.

c. Pengajar menjelaskan pula mengenai strategi pembelajaran matematika yang berupa pemahaman mandiri melalui serangkaian pertanyaan pemahaman, pertanyaan skematis yang berguna untuk menjembatani siswa kepada konsep yang baru. Melalui pertanyaan strategi dan refleksi, siswa di arahkan untuk menyelesaikan permasalahan berupa soal-soal latihan.

Selain itu pemberian cerita para matematikawan pada saat apersepsi dapat meningkatkan prestasi belajar siswa. Dan lebih efektif jika diberikan secara rutin. Brown, Eade dan Wilson (1999) mengungkapkan gagasan bagaimana menyelesaikan penjumlahan seperti $7+$ ? $=23$. Persamaan ini diubah menjadi $7+x=23$. Pemisalan $x$ dalam persamaan ini merupakan bentuk metafora (metaphorical substitution). Selain itu, penyelesaian persamaan dapat dilakukan dengan mengubahnya ke dalam model geometri. Sedangkan Danesi (2007) mengaplikasi metafora untuk mengongketkan suatu permasalahan matematis yang abstrak. Suatu permasalahan dijelaskan dengan 
bahasa yang sederhana serta menggunakan tehnik diagram dengan tujuan siswa dapat melihat secara langsung, sehingga siswa dapat menyelesaikannya dengan mudah dan dapat menyelesaikan permasalahan berikutnya dengan lebih baik. Misalnya pada permasalahan sistem.

Selanjutnya Bolite frant, et al. (2006) dalam penelitiannya tentang metafora dalam kelas matematika: menganalisis proses pembelajaran yang dinamis pada grafik fungsi, menemukan bahwa penggunaan beberapa metafora (orientasi, gerak fiktif, ontologi, dan campuran metafora) muncul dalam percakapan guru dan siswa. Patrick Bahls (2009) melakukan penelitian tentang methafora yaitu penggunaan puisi dalam mengajarkan matematika pada pokok bahasan grafik fungsi trigonometri.

Di akhir pembelajaran metafora dapat digunakan sebagai proses menyimpulkan. Apa yang kalian pelajari hari ini? Apa pula yang telah kalian pelajari tentang diri kalian sendiri dalam menyelesaikan permasalahan yang ada? Adakah rencana ke depan untuk senantiasa memperbaiki kualitas diri? Bagaimana cara kalian mewujudkan upaya tersebut?"

Berikut ini diberikan sebuah contoh tentang penggunaan metafora pada materi teorema Phytagoras. Langkah-langkah pembelajaran matematika menggunakan Metafora pada materi teorema Phytagoras yang dilaksanakan dalam penelitian ini, sebagai berikut :

1. Pendahuluan

a. Apersepsi

1) Melalui tanya jawab, guru mengingatkan kembali siswa mengenai materi bangun datar yang telah dipelajari.

2) Guru menginformasikan materi yang akan dipelajari serta tujuan kegiatan pembelajaran.

\section{b. Motivasi}

Guru menceritakan kisah singkat tentang Phytagoras sebagai penemu teorema Phytagoras yang terkenal (Metafora 1)

2. Kegiatan Inti

a. Guru membimbing siswa dalam pembentukan kelompok yang disusun berdasarkan kemampuan heterogen (siswa pandai, sedang dan kurang)

b. Guru membagikan teks materi tentang segitiga siku-siku pada tiap siswa.

c. Secara kelompok siswa mendiskusikan teks materi, kemudian menjawab soal yang terdapat di dalam teks materi.

d. Sambil mengawasi jalannya diskusi, guru menceritakan tentang kisah sukses Thomas Alva Edison (Metafora 2)

e. Guru membimbing siswa untuk membuat kesimpulan sementara dan meminta anggota masing-masing kelompok untuk mengkomunikasi- kan hasil kesimpulannya di depan kelompok lain.

f. Guru menanggapi jawaban siswa dan memberikan informasi yang benar jika terdapat kelompok yang masih keliru dalam menarik kesimpulan. 
3. Penutup

a. Guru bersama siswa membuat kesimpulan / rangkuman hasil belajar.

b. Guru memberikan tes individual untuk mengetahui daya serap materi yang baru saja dipelajari.

c. Guru mengawasi siswa yang sedang mengerjakan soal tes.

d. Setelah siswa selesai mengerjakan tes, guru menceritakan tentang biografi tokoh matematika Al-Khawarizmi (Metafora 3)

\section{Kelebihan Penggunaan Metafora dalam Pembelajaran Matematika}

Tidak ada satupun metode, model atau strategi yang sempurna sehingga dapat dipakai untuk semua pembelajaran. Masing-masing memiliki kelebihan dan kekurangan. Adapun kelebihan dari penggunaan metafora dalam pembelajaran matematika antara lain sebagai berikut:

1. Pemberian metafora dapat dilakukan di setiap bagian ketika proses pembelajaran berlangsung. Diharapkan siswa tidak merasa bosan dan lebih rileks dalam mengikuti pembelajaran.

2. Metafora-metafora yang dapat diberikan sangat bervariasi sehingga pengajar dapat menyesuaikan metafora yang cocok dengan materi pembelajaran secara leluasa.

3. Metafora dapat dijadikan sebagai alat untuk menyampaikan pesan-pesan moral yang terkandung di dalam konsep-konsep matematis atau nilai-nilai kehidupan.

4. Dengan metafora, siswa diberi kesempatan yang luas untuk memikirkan dan merenungkan segala sesuatu yang ada disekitarnya. Di sini siswa diajak untuk mengonstruksi konsep matematis dari apa yang dilihat, dikerjakan, dan kemudian didiskusikan.

5. Pemberian metafora dapat meningkatkan minat dan motivasi belajar siswa.

Banyak kelebihan yang dimiliki oleh metafora dalam pembelajaran matematika. Apakah kita mau menggunakannya atau tidak. Paradigma tentang matematika merupakan mata pelajaran yang sulit harus kita ubah menjadi pelajaran yang mudah dan menyenangkan.

Untuk dapat membuat siswa tertarik kepada mata pelajaran matematika, cara yang paling tepat adalah melalui gurunya. Apabila siswa sudah menyukai gurunya, maka apa yang disampaikan gurunya akan diikuti dengan sungguh-sungguh yang pada akhirnya akan mengukai mata pelajaran yang diajarkan.

\section{VII.Penutup}

Metafora merupakan suatu strategi yang digunakan guru untuk memudahkan anak dalam memahami apa yang diberikan oleh guru. Karena itu metafora harus direncanakan dengan baik, sehingga penggunaannya dalam pembelajaran dapat 
maksimal.

Sebagai seorang guru, apalagi guru matematika. Kita ditantang untuk dapat menjadikan matematika sebagai mata pelajaran yang disukai oleh anak, bukan sebaliknya menjadi mata pelajaran yang ditakuti oleh siswa. Oleh karena itu, mari kita jadikan matematika itu indah dan menyenangkan.

Berikut ini ada beberapa kiat yang dapat dilakukan oleh guru matematika agar siswa lebih mencintai matematika

1. Ubahlah penampilan agar menjadi menarik dan menyenangkan

2. Sebelum masuk ke kelas, tinggalkan semua beban pikiran yang ada. Pusatkan perhatian kepada siswa dan materi yang akan diajarkan

3. Dalam penyampaian materi, janganlah terlalu tegang. Bersikaplah secara rileks agar memudahkan siswa menyimak apa yang disampaikan

4. Perbanyak memberi pujian dan kurangilah hukuman kepada siswa

5. Gunakan metafora pada setiap kesempatan yang ada

6. Sampaikan manfaat dari apa yang dipelajari

\section{DAFTAR PUSTAKA}

DePorter, Bobbi; Reardon, Mark; dan Nourie, Sarah Singer. (2000). Quantum Teaching: Mempraktikkan Quantum Learning di Ruang-ruang Kelas. Bandung: Kaifa.

Bolite Frant, J.; Acevedo, J.I.; Font, V. (2006). metaphors in mathematics classrooms: analyzing the dynamic process of teaching and learning of graph functions. Actas del CERME 4 (pp. 82-91)

Brown, T.,Eade, F. and Wilson, D. (1999). "Semantic Innovation: Arithmetical and Algebraic Metaphors Within Narratives of Learning”. Educational Studies in Mathematics. 40, 53-70.

Danesi, M. (2007). “A Conceptual Metaphor Framework for the Teaching of Mathematics". Studi Philos Educ 26, 225-236.

Herman, T. (2006). Pembelajaran Berbasis Masalah untuk Meningkatkan Kemampuan Berpikir Matematis Tingkat Tinggi Siswa SMP. Disertasi Doktor SPS UPI Bandung: Tidak diterbitkan.

Holil, Anwar. (2007) Model Pembelajaran Kooperatif. http://www.blogger.com/feeds/posts/

Hudojo Herman. (1988). Mengajar Belajar Matematika. Jakarta: Departemen Pendidakan dan Kebudayaan Direktorat Jenderal Pendidikan Tinggi Proyek Pengembangan LPTK.

Lakoff, G. \& Núñez, R. (2000). Where mathematics comes from: How the embodied mind brings mathematics into being. New York: Basic Books. 
Maksum. (2003). "Upaya Meningkatkan Motivasi Belajar Matematika Melalui Cerita Para Matematikawan". Jurnal Pendidikan Mipa. 3, (1), 33-37.

Maulana. (2008). Penggunaan Metafora dalam Perkuliahan Matematika. http://hidup-penuhperjuangan.blogspot.com. [22 Desember 2010]

Ruseffendi, E.T. (2006). Pengantar kepada Membantu Guru Mengembangkan Kompetensinya dalam Pengajaran Matematika untuk Meningkatkan CBSA. Bandung: Tarsito.

Sapa'at, A. (2007). "Penggunaan Metafora dalam Pembelajaran Matematika". Jurnal Matematika dan Pendidikan Matematika (ALGORITMA). http://www.lpidd.net/web/download/

Soejadi. (2000). Kiat Pendidikan Matematika di Indonesia. Jakarta: Direktoran Jenderal Pendidikan Tinggi Departemen Pendidikan Nasional.

Wenger, W. (2004). Beyond Teaching \& Learning Memadukan Quantum Teaching \& Learning. Bandung: Nuansa. 